\title{
都市緑化樹木を対象とした大型重量計による単木蒸散量の計測と 樹木の形態的・生理的特徵に基づく分析

\author{
WEIGHING WHOLE TREE TRANSPIRATION RATE OF URBAN TREES \\ AND ANALYSIS OF TREE'S MORPHO-PHYSIOLOGICAL EFFECTS
}

\author{
清野友規*, 浅輪貴 史 ${ }^{* *}$, 梅干野 昆 ${ }^{* * *}$, 清 水克哉**** \\ Tomoki KIYONO, Takashi ASAWA, Akira HOYANO \\ and Katsuya SHIMIZU
}

\begin{abstract}
The purpose of this study is to grasp the variation of whole tree transpiration rates and capacities of container-grown isolated trees and to analyze tree's morpho-physiological effects. We developed hanging-type gravimeter and weighed 11 species $(\mathrm{h}=3 \sim 6.7 \mathrm{~m})$. We found (1)Daily water use in summer irrigation days were $10 \sim 30 \mathrm{~kg}$, equivalent to $0.62 \pm 0.36$ times of water evaporation from the same size of crown projection area, (2)Maximum latent heat was $2.3 \mathrm{~kW} /$ tree, (3)Same tree's capacity can change threefold due to physiological change, (4)Ring-porous species tend to use much water, which suggest the significance of hydraulic capacity under volume-restricted soil condition.
\end{abstract}

Keywords: Greening, Thermal environment, Transpiration, Gravimetric measurement, Tree form, Stomatal movement 緑化，温熱環境，蒸散，重量測定，樹形，気孔開閉

1. はじめに

\section{1-1. 研究背景}

アスファルト舗装やコンクリート建造物によって悪化した都市の 温熱環境の改善策として, 都市緑化樹木の蒸散による気温上昇抑制 効果が期待されている. しかしながら, 都市空間への熱的影響の評 価や，それに基づく緑化空間設計，灌水計画等を行う上で不可欠な， 都市緑化樹木の単木スケールでの蒸散量の定量的な実態は明らかで ない. この原因として, (1)信頼性の高い単木蒸散量の実測データが 不足している問題と, (2)蒸散が測定環境 (日射量, 土壌水分等) と 対象樹木の特性の双方に強く依存するために, 実測のみによる一般 化が困難であるという問題が挙げられる.

(1)について，表1に単木蒸散量の計測・推定手法を示す．既往の 手法として, 樹液流法, ポロメーター等によって計測した個葉の蒸 散速度に別途計測した葉面積を乗じる手法, ライシメーター（重量 計測）法がある. 樹液流法1-2) は森林水文学分野で最も一般的な手法 であるが, 樹種 (木部構造) 毎の較正抜きには2倍以上の系統誤差を 生じうる3) 他, 樹木サイズによって樹液流速と蒸散速度に最大で 2 時 間以上の時間差が生じうる4)ことも知られ，また中でも Granier法1) はセンサー温度差から樹液流速を推定する原理上, 夏季の都市空間 のような日射・気温変化の大きな環境での精度にも課題がある5). 個 葉の計測値から単木蒸散量を推定する手法は, 葉面積分布の測定誤 差, 樹冠内における個葉特性の違い, 樹冠内の微気象の再現性が全 て影響するために精度は高くなく, 別の計測手法の検証抜きに単
Table 1 Comparison of measurement methods in previous studies

\begin{tabular}{|c|c|c|c|c|}
\hline 計測方法 & $\begin{array}{c}\text { 単木スケール } \\
\text { での精度 }\end{array}$ & 樹種の比較 & 時間応答性 & $\begin{array}{c}\text { 孤立樹木の } \\
\text { 既往研究 }\end{array}$ \\
\hline 樹液流法 & $\triangle$ & $\triangle$ 較正必須 & $\begin{array}{c}\text { サイズ依存 } \\
\sim 2 \text { 時間 }\end{array}$ & 文献 9-11) \\
\hline $\begin{array}{l}\text { ポロメーター等の個 葉 } \\
\text { 計測（\&葉面積計測） }\end{array}$ & $x$ & $\begin{array}{c}\text { 個葉スケール } \\
\text { では○ }\end{array}$ & 数分 & 文献 11-13) \\
\hline ライシメーター法 & 0 & 0 & 数 10 分 & 文献 7-8) \\
\hline
\end{tabular}

独で用いることは困難である6 ${ }^{6 \text { 注1 } 11}$. ライシメーター法は最も精度が 高い計測手法であるが，大規模な設備を要するため報告事例が限ら れている。そこで筆者らは，熱環境の予測評価への応用を目的とし た蒸散データには, 配置や樹種の検討への応用が容易な単木スケー ルでの算出と熱環境の日変化に対応した 1 時間以下の時間分解能が 求められるとの認識に立ち, 長期的なケヤキの重量計測を行ってき た7-8).

一方，(2)について, 実測によって得られた知見を一般化し蒸散量 の予測に応用するためには, 数値モデルを用いて測定環境の影響と 樹木の影響を分離し，樹木の蒸散能力をパラメータとして表すこと が有効と考えられる．水文学分野では気孔コンダクタンスや可能蒸 発量比(Potential evaporation ratio) といったパラメータが算定さ れ，更に，葉齢や樹形等の樹木の特徵に基づいたパラメータの比較 分類も行われている14-15)。熱環境評価や灌水計画のための蒸散予測 でも樹木の特徵による分類は有用な可能性があるが，都市緑化樹木 に対しては（信頼性の高いデータが少ないという(1)の問題とも関連

\footnotetext{
本論文は既報 45-46)に加筆修正を加えたものである

* 東京工業大学 大学院生・修士 (工学)

** 東京工業大学 准教授・博士 (工学)

*** 放送大学 教授. 工博

****トヨタ自動車バイオ・緑化研究所
}

Grad. Stud., Tokyo Institute of Technology, M. Eng.

Assoc. Prof., Tokyo Institute of Technology, Dr. Eng.

Prof., The Open University of Japan, Dr. Eng.

TOYOTA Motor Corporation, Biotechnology \& Afforestation Business Div. 
Table 2 Measurement period \& morpho-physiological characteristics of sample trees

\begin{tabular}{|c|c|c|c|c|c|c|c|c|c|c|c|}
\hline 樹種 & 略記 & $\begin{array}{c}\text { 重量計測期間 } \\
\text { (分析対象期間) }\end{array}$ & $\begin{array}{l}\text { 樹冠投影面積 } \\
\text { (8点推定) }\left[\mathrm{m}^{2}\right]\end{array}$ & $\begin{array}{c}\text { 樹高 } \\
\text { [m] }\end{array}$ & $\begin{array}{c}\text { 基部直径 } \\
{[\mathrm{cm}]}\end{array}$ & $\begin{array}{c}\text { 生枝下直径 } \\
{[\mathrm{cm}]}\end{array}$ & $\begin{array}{l}\text { 葉齢 } \\
\text { [月] }\end{array}$ & 道管種 & 耐陰性 24) ** & 耐乾性 24$) * *$ & 街路樹数 ${ }^{20)}$ \\
\hline \multirow{2}{*}{ ケヤキ } & \multirow{2}{*}{ Z. $s$. } & $(2010 / 08 / 1-31)^{*}$ & 5.5 (葉面積 $15.4 \mathrm{~m}^{2}$ ) & 6.4 & - & 10 & \multirow{2}{*}{ 落葉樹 } & \multirow{2}{*}{ 環孔材 } & \multirow{2}{*}{ 2. 1} & \multirow{2}{*}{ 3. 4} & \multirow{2}{*}{ 3位 } \\
\hline & & $(2012 / 08 / 1-31)^{*}$ & 9.2 (葉面積 $28.9 \mathrm{~m}^{2}$ ) & 6.4 & - & 11 & & & & & \\
\hline \multirow{2}{*}{ シラカシ } & \multirow{2}{*}{ Q. $m}$. & $2012 / 07 / 29-08 / 09$ & 3.3 & 5.5 & 12 & 10 & \multirow{2}{*}{ 常緑樹 (36) } & \multirow{2}{*}{ 散孔材 } & \multirow{2}{*}{ 2. 3} & \multirow{2}{*}{4} & \multirow{2}{*}{ 13位 } \\
\hline & & $2013 / 08 / 18-21$ & - & - & 12 & 10 & & & & & \\
\hline エゴノキ & S. $j$. & $2012 / 07 / 29-08 / 09$ & 6.6 & 4. 4 & 11 & 9 & 落葉樹 & 散孔材 & 2.5 & 2.5 & 66 位 \\
\hline ソメイヨシノ & C. $\times y$. & 2012/08/01-08 & 7. 8 & 5.5 & 14 & 10 & 落葉樹 & 散孔材 & - & - & 2位 \\
\hline イチョウ & G. $b$. & $2012 / 08 / 10-22$ & 4. 5 & 5.4 & 13 & 10 & 落葉樹 & 仮道管 & 1. 3 & 4 & 1位 \\
\hline コナラ & Q. $s$. & $2012 / 08 / 10-22$ & 7. 3 & 5.8 & 14 & 9 & 落葉樹 & 環孔材 & 3 & 3 & 79位 \\
\hline クスノキ & C.c. & $2012 / 08 / 12-23$ & 3. 6 & 4. 7 & 13 & 9 & 常緑樹 (12) & 散孔材 & 3.5 & 2. 8 & 6位 \\
\hline ヤマボウシ & B. $j$. & $2012 / 08 / 24-09 / 05$ & 6.9 & 4. 5 & 12 & 9 & 落葉樹 & 散孔材 & - & - & - \\
\hline シデコブシ & M. s. & $2012 / 08 / 24-09 / 05$ & 1.5 & 3. 0 & 6 & 5 & 落葉樹 & 散孔材 & 3 & 1.8 & - \\
\hline クヌギ & Q. $a$. & $2012 / 08 / 24-09 / 05$ & 7.5 & 6.7 & 11 & 8 & 落葉樹 & 環孔材 & 2. 3 & 4 & 98位 \\
\hline コブシ & M. $k$. & $2012 / 09 / 05-09 / 26$ & 6.1 & 4. 1 & 13 & 8 & 落葉樹 & 散孔材 & 3 & 2. 9 & 19位 \\
\hline
\end{tabular}

$* 2010$ 年8月〜2013年まで連続計測＊*温帯806樹種中の5段階相対評価

(て), 単木スケールでの蒸散能力の算定・比較は殆ど行われてこな かった。近年，孤立環境にある都市緑化樹木が森林に比べより多く の蒸散を行う可能性が指摘されている16-17) ように, 都市と森林では 気象条件や根系の状態が大きく異なるために，森林で得られた知見 (樹種によって蒸散量がどれだけ変わるか, 既存の分類基準が予測に 有用であるか等）が適用可能か否かは明らかでない。

\section{1-2. 研究目的と研究対象の位置づけ}

本研究では, 孤立環境にあるコンテナ植栽の樹木を対象として, 1 時間単位での蒸散速度と蒸散能力の樹種または個体による差異を 把握することを目的とし, 可能蒸発量比を用いて, 樹木の形態的・ 生理的特徵との関係および既往研究15) の温帯広葉樹林の值との比 較分析を行う。そのために, 前記の長期計測を目的とした重量計測 手法に加え, 短期間での複数個体の計測を可能とする吊り下げ式重 量計測法を新たに開発し，11樹種を対象に実験围場において単木蒸 散量の計測を行った。本研究では土壌容積を $0.5 \mathrm{~m}^{3}$ で統一した供試 木（幹径約 $10 \mathrm{~cm}$ ）を対象としている注 2 ) が，一般に地上部（葉面積・ 幹径) と根の成長には相関がある18) ため, 本研究の結果はこのサイ ズの都市緑化樹木の蒸散能力の目安になり得るものと考えられ, こ の条件内においては数值シミュレーション19) やCASBEE-HI ${ }^{13)}$ 等 による屋外熱環境評価の検証にも応用できるものと考えられる.

本研究では夏季晴天・灌水日の計測結果を報告する。ここでは, (1)舗装や植栽升によって土壌容積が制限された条件, (2)街路樹や庭 木のような孤立環境にあり風や日射の影響を受けやすい条件，(3)十 分に灌水された条件にある都市緑化樹木を想定対象としているが, この結果は実際の都市において既に灌水されている樹木だけでな く, 現状で水不足の状態にある樹木を適切に管理した場合に期待さ れる効果を検討する上でも有用な知見を提供するものである.

\section{2. 研究対象と方法}

\section{2-1. 測定環境と供試木}

実測は 2012 年夏季を中心に, 愛知県みよし市内にあるトヨタ自動 車バイオ・緑化研究所 $\left(35^{\circ} 8^{\prime} \mathrm{N}, 137^{\circ} 6^{\prime} \mathrm{E}\right)$ の実験圃場で行った. 図1に 围場内と実測の様子を, 図 2 に供試木の配置を示す. 本研究では孤立 環境と土袞容積の制限を想定し, 平均樹高 $5.2 \mathrm{~m}$ のコンテナ植栽を供 試木として, 隣接樹木の樹影が被らないように $4 \mathrm{~m}$ 以上の間隔を取っ て配置した。 土壤容積は面積 $1 \mathrm{~m}^{2}$, 深さ $50 \mathrm{~cm}$ (排水層 $10 \mathrm{~cm}$ ), 土壌 種はローム土 $70 \%$, 真珠岩パーライト $20 \%$, 腐植土 $10 \%$ とした。
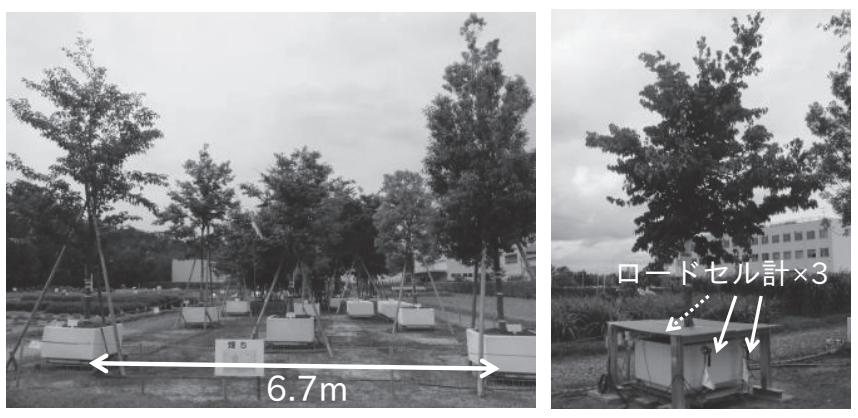

Fig. 1 Farm field (left), weighing B.j. with load cells (right)

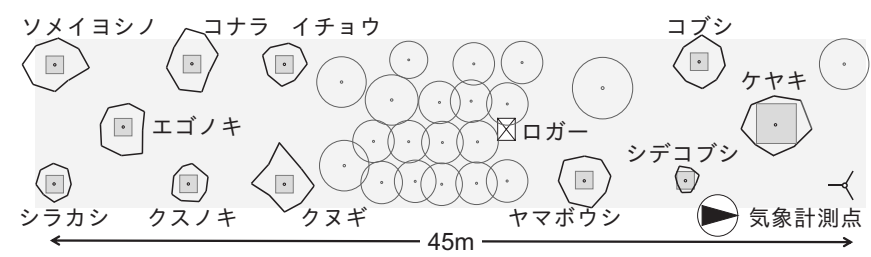

Fig. 2 Plot plan of farm field (summer 2012)

表 2 に供試木の形態的・生理的特徵と計測期間を示す. ケヤキ (Zelkova serrata), シラカシ(Quercus myrsinifolia), エゴノキ (Styrax japonica), ソメイヨシノ(Cerasus × yedoensis), イチョウ (Ginkgo biloba), コナラ(Quercus serrata), クスノキ(Cinnamomum camphora), ヤマボウシ(Benthamidia japonica), シデコブシ (Magnolia stellata), クヌギ(Quercus acutissima), コブシ (Magnolia kobus) の11種, 各1本を対象とした。樹種の選択は, 緑 化樹種としての一般性20) を考慮した上で, 既往研究で蒸散特性への 影響が報告されている, 葉への水供給能力を決める道管種 ${ }^{21)}$, 光合 成速度・気孔開度と相関のある葉齢 (常緑・落葉) 22-23) の影響を検討 するために決定した．なお供試木は計測開始前に各樹種2本ずつ用 意して圃場内で養生させた後, 生育の良かったものを選んだ.

土壌が乾燥状態にある個体は樹種に関わらず蒸散が抑制されるこ とが知られている23) ため, 供試木ごとの蒸散能力の把握という本研 究の目的から, 途中灌水停止実験を行っていた期間以外では戋場容 水量まで毎日灌水した状態で養生を行った.

大半の供試木は2011年から図2中の位置に配置していたが，シラ カシだけは2012年の実測前まで圃場中央部の植栽群内にあった。ま 
た, ケヤキの 2010 年夏季の実測結果は浅輪ら $(2012,2014)$ で既に報 告している1-2) が, 当時のケヤキはコンテナに移植する際に樹木一の 負担を軽減させる目的から枝打ちを行っていたために自然状態より 葉面積が減少しており, その後の 2 年間で葉面積の増大が見られた (表2). この2樹種は蒸散特性にも変化が確認されたため, 特性変化 後のケヤキ 2012 年とシラカシ 2013 年も本研究の分析対象とした.

\section{2-2. 計測機器と手順}

表3に計測項目と機器の概要を示す．ケヤキの重量は2010 2013 年まで台科上で連続的に, 気象条件は圃場内の代表点 (図2, 機器設 置高さは全て地上 $5 \mathrm{~m}$ ) で計測し, データロガー(Campbell, CCR1000)に記録した。 戋場内には, 樹木群の南側10m位置に温室 （高さ $4 \mathrm{~m}$ ）がある他は周辺 $40 \mathrm{~m}$ 以内に建物・樹木等は存在しない. 計測機器・データ処理の詳細は浅輪ら $(2012,2014) 7-8)$ を参照された い. 各供試木の投影面積やケヤキの葉面積等の樹木形状の計測には 地上型レーザースキャナーを用い, 投影面積は計測した点群データ を基に樹冠外周上から $45^{\circ}$ 間隔で 8 点選び計算した. ケヤキの葉面積 の推定手法の詳細はAsawa et al. (2014) 25) を参照されたい. 本研究 の供試木と同サイズのケヤキを用いてレーザー計測と刈取りによる 検証を行い, 誤差 $20 \%$ 以下で推定可能であることを確認している.

図3に本研究で開発した吊り下げ式重量計の模式図を示す. ケヤ キ以外の 10 種の試験体重量は, 鉄骨製の支持フレーム上の 3 点から $\mathrm{S}$ 字ビーム型ロードセル(ミネベア, U3S1-500K-NS, 积量 $500 \mathrm{~kg}$, 表 示分解能 $0.1 \mathrm{~g}) 3$ 台とコンテナを設置した台座を連結し, レバーブロ ックを操作して吊り上げることで計測を行った．従来の台科方式と 比較して, 着脱・持ち運びが容易なロードセル (本体重量 $2.6 \mathrm{~kg}$ ) と手 動操作のレバーブロックを用いることで, 各試験体を移動させるこ となく計測が可能なことが特徵である. 試験体重量が $500 \mathrm{~kg}$ を超え る本研究の場合, 台科式では試験体の移動に重機が必要となるため に複数個体を計測する上での本方式の利点は大きい. 一方で久点と して風による計測值の振動が大きくなる点がある. 重量計は計3台 作成して, 同時に3個体ずつ, 2012年夏季を中心に各 10 日程度計測 し(表2)，1秒または 5 秒間隔で記録した.

供試木ごとの最大蒸散能力の把握という目的から, 灌水は全て管 理し, 根への酸素供給を確保しつつ雨の侵入と土壌面からの蒸発を 防ぐためコンテナ上部を天板で覆った。 ケヤキ以外の試験体の排水 量は計測していないが, 排水が日中の蒸散速度推定に影響しないよ うに, ケヤキの実測結果7)より灌水開始から約 4 時間で排水が終わる ことを確認した上で, 主に深夜に灌水を行うことで対処した. 図4に 試験体重量と土壤含水率の計測結果を示す. 灌水日では, 供試木ご とに概水一定した日重量変化や灌水直後の急激な重量の減少が見ら れ, 固場容水量まで十分に灌水されていることが分かる. なお乾燥 ストレス応答を調べる目的から計測期間中に灌水停止実験を行って いるが, 本研究では灌水日のみを評価対象とし, 雨天日 (2012年8月 $3,6,11,14,18,30$ 日，9月 1, 2, 11, 15, 19, 20日) も対象外とした.

\section{3. 蒸散速度の推定方法と誤差評価}

\section{3-1. 重量の推定と正規性の検討}

屋外での重量計測から蒸散速度を求める場合は風の影響を評価す る必要があり, 吊り下げ計測では特に重要な問題となる. 表4に吊り 下げ式重量計による, 晴天日における樹種・風速別の30分間の標準
Table 3 Measurement equipment

\begin{tabular}{|c|c|c|}
\hline 計測項目 & 機器 & 記録間隔 \\
\hline 試験体重量 & ロードセル (ミネベア, U3S1-500K-NS) 各3台 & 1 or 5 [sec] \\
\hline $\begin{array}{l}\text { 樹冠投影面積 } \\
\text { 葉面積 (ケヤキのみ) }\end{array}$ & 地上型レーザースキャナー(RIEGLE, VZ-400) & $\begin{array}{l}\text { 全樹種2012年 } \\
\text { 2010, 2012年 }\end{array}$ \\
\hline 排水量 (ケヤキのみ) & 転倒升式雨量計 (Campbe I I, TE525-L25) & $10[\mathrm{~min}]$ \\
\hline 気温 & $\begin{array}{c}\text { 強制通風筒 (Young, YG-43520) } \\
\text { 白金抵抗温度計 (4線式Pt100 } \Omega \text { ) }\end{array}$ & 1 [min] \\
\hline 相対湿度 & 静電容量式高分子湿度センサー & 1 [min] \\
\hline 水平面全天日射量 & サーモパイル式日射計 (英弘精機, MS-402) & 1 [min] \\
\hline 風向 · 風速 & 三次元超音波風向風速計 (Young, YG-81000) & 1 [sec] \\
\hline 樹冠放射温度 & 赤外線放射カメラ (NEC Avio, ThermoGEAR) & 1 [hour] \\
\hline
\end{tabular}

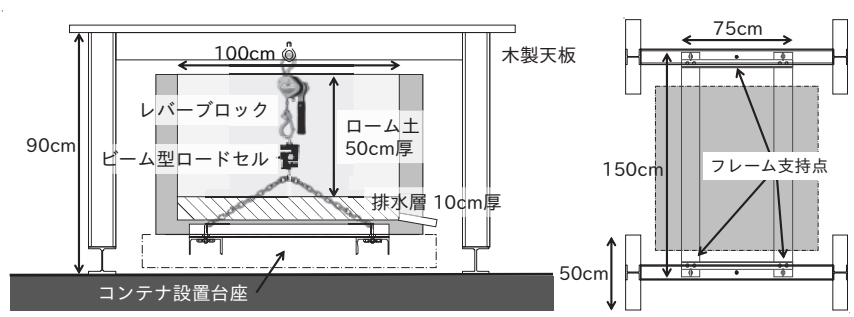

Fig. 3 Design of hanging-type gravimeter

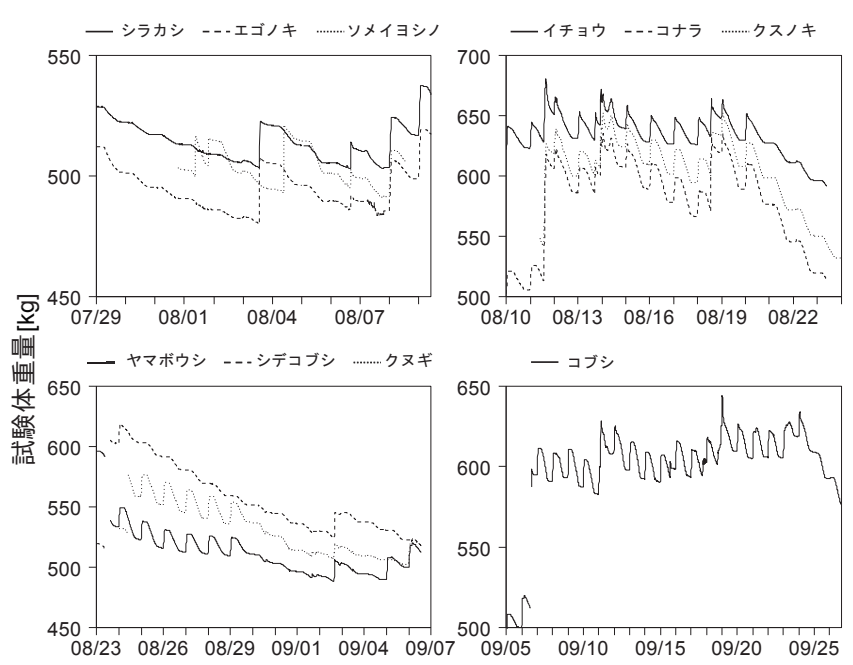

Fig. 4 10-min avg. sample weight, scale of $\mathrm{x}$-axis indicate midnight

偏差の平均值を示す.データの分析には統計解析環境 R ver.3.12 ${ }^{26)}$ を用いた。供試木の日中の蒸散速度は約 $1 \sim 3 \mathrm{~kg} / \mathrm{tree} / \mathrm{h}$ と想定された が，風速 $2 \mathrm{~m} / \mathrm{s}$ 以下の条件においても多くの供試木で標準偏差が $1 \mathrm{~kg} / \mathrm{tree} / \mathrm{h}$ を超える振動が見られた。そこで本研究では相対誤差 (95\%信頼区間)の許容值を $20 \%$ と定め注3) , 重量を秒単位の高分解能 で記録することで重量の推定精度の向上を図った，重量計による蒸 散計測では往々に移動平均による平滑化が行われる27) が, 測定誤差 が定量化されない他, 長すぎる平均化時間は定常性の仮定を崩すた めに誤差を生じやすい問題がある. 本研究では 1 時間単位の蒸散速 度を議論するため, 既往研究の樹液流の計測結果から 30 分間は蒸散 速度が定常と判断して, 各時刻の重量を前後15分間( $\mathrm{n}=1801$ or 361) の直線回帰から求めた. 表 4 に直線回帰の残差から求めた樹種・風速 別の高次モーメントの平均值を示寸. 風速 $2 \mathrm{~m} / \mathrm{s}$ 以下では歪度の絶対 值は殆どの供試木で1以下, 尖度はソメイヨシノ, ヤマボウシ, クヌ 
Table 4 Descriptive statistics of sample weight (half hourly basis)

\begin{tabular}{|c|c|c|c|c|c|c|c|c|c|}
\hline \multirow{2}{*}{$\begin{array}{c}\text { 平均風速 } \\
{[\mathrm{m} / \mathrm{s}]}\end{array}$} & \multicolumn{3}{|c|}{ 標準偏差 } & \multicolumn{3}{|c|}{ |歪度 | } & \multicolumn{3}{|c|}{ 尖度 } \\
\hline & $\sim .5$ & $.5 \sim 2$. & 2. & $\sim .5$ & $.5 \sim 2$. & 2. & $\sim .5$ & $.5 \sim 2$. & 2. \\
\hline シラカシ & 0.22 & 0.37 & 0.72 & 0.06 & 0.20 & 2. 11 & 2. 01 & 4. 00 & 48.7 \\
\hline エゴノキ & 0.17 & 0.82 & 0.62 & 0.05 & 0.54 & 1. 43 & 2. 14 & 4. 97 & 7. 40 \\
\hline ソメイヨシノ & 0.07 & 0.28 & 0.47 & 0.21 & 1.05 & 1. 12 & 3. 81 & 9. 24 & 9.80 \\
\hline イチョウ & 0.67 & 0.78 & 1. 78 & 0.25 & 0.44 & 0.51 & 4. 20 & 34 & 7. 24 \\
\hline コナ & 0.65 & 1. 28 & 3. 45 & 0.14 & 36 & 0.22 & 0 & 3 & 84 \\
\hline クスノキ & 0.62 & 0.88 & 1. 56 & 0.41 & 0.59 & 0.47 & 4. 08 & 5. 82 & 6. 72 \\
\hline ヤマボウシ & 0.42 & 0.44 & 0.41 & 0.18 & 0.73 & 1. 10 & 3. 24 & 7. 46 & 8. 84 \\
\hline シデコブシ & 0.21 & 0.51 & 0.27 & 07 & 16 & 33 & .10 & .10 & 5. 22 \\
\hline クヌギ & 0.43 & 0.48 & 1. 32 & 0.62 & 0.67 & 2. 00 & 5. 00 & 6. 27 & 31.2 \\
\hline コブシ & 0.14 & 0.35 & 0.87 & 0.37 & 1. 04 & 1. 24 & 4. 64 & 7. 27 & 7. 84 \\
\hline
\end{tabular}

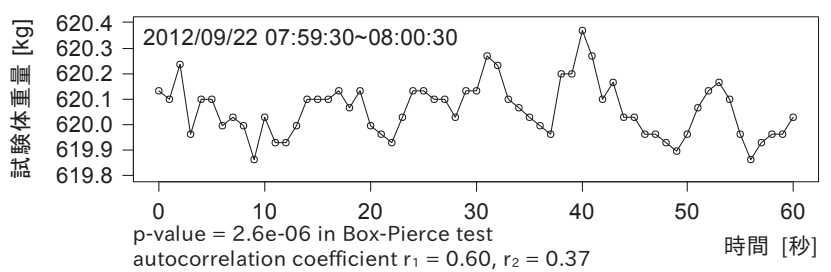

Fig. 5 Weight change of M.k., example of autocorrelation

ギ，コブシ以外では 6 以下であり正規分布からのずれは顕著ではな いが，風速 $2 \mathrm{~m} / \mathrm{s}$ 以上では殆どの供試木で大幅な值の増加が見られ た. 特に歪度の増大は平均值を代表値として扱う上で大きな問題と なるため, 本研究では日中の平均風速が $2 \mathrm{~m} / \mathrm{s}$ を超える強風日 $(2012$ 年8月 $1,15,31$ 日，9月 $14,17,18$ 日) を評価対象外とした.

\section{3-2. 独立性の検討と信頼区間の推定}

エルゴード過程では標本数を増やすことで標準誤差を減らせる が，一般に時系列データの多くは自己相関を持つために疑似反復を 犯しやすい. 本研究でも図5に示すように, 重量データが 10 秒程度の 間隔で大きく振動しており，各值が独立でないことが確認された． 1秒という計測間隔がコンテナの振り子運動周期より短いために, 慣性の影響で直前の計測值に近い值が表れているものと考えられ る. 従って，ここでは実効的に独立な標本間の時間(Time between effectively independent observation) 28-29) を推定することで，各時 刻の重量推定值の信頼区間を補正した。
自己相関のある標本系列の自由度（有効標本数 $N_{\text {eff }}$ ） は実効的に 独立な標本間の時間 $T_{0}$ で標本数 $N$ を割ることで得られ，平均に関す る $T_{0}$ は不偏推定のアナロジーから(2)式で表せる28-29).

$$
\begin{gathered}
N_{\text {eff }}=\frac{N}{T_{0}} \\
T_{0}=\sum_{L=-N}^{N}\left(1-\frac{|L|}{N}\right) r_{L}=1+2 \sum_{L=1}^{N}\left(1-\frac{L}{N}\right) r_{L}
\end{gathered}
$$

ここで, $N_{e f f}$ : 有効標本数, $N$ : 標本数, $T_{0}$ : 実効的に独立な標本間 の時間, $L:$ ：グ次数, $r_{L}$ : L次ラグの自己相関係数である. 1次のマ ルコフ過程は自己回帰(AR)モデル(3)式で表現され， $N$ が十分大きい 時には(2)式第 2 項以降を 1 次の自己相関係数 $r_{1}$ を公比とする等比級 数とみなせることから(4)式の近似が成り立つ.

$$
\begin{gathered}
x(t)=r_{1} x(t-1)+\varepsilon(t) \\
T_{0}=1+2 \sum_{L=1}^{N}\left(1-\frac{L}{N}\right) r_{1}^{L} \approx \frac{1+r_{1}}{1-r_{1}}
\end{gathered}
$$

ここで, $x(t)$ : 任意の時系列データ, $r_{1}: 1$ 次ラグの自己相関係数, $\varepsilon(t)$ : 時刻 $t$ の誤差項である. 本研究では直線回帰の残差系列に誤差 の正規性を仮定した1次のARモデルをあてはめ, Yule-Walker法に よって $r_{1}$ を決定して各時刻の $N_{e f f}$ と蒸散速度の信頼区間を求めた.

シラカシ 2012 年は最も蒸散量が少なく相対誤差が大きな個体で あったため,ここではシラカシ2012年の誤差評価結果を示す。計測 間隔1秒のデータから求めた 1 時間ごとの重量変化（蒸散速度）とそ の 2 標準誤差 $(\approx 95 \%$ 信頼区間 $), N_{e f f}$ と気象条件を図6に示寸. 試験 体の振動が激しくなるにつれて自己相関が弱まるため, $N_{e f f}$ は概ね 風速に対応していた。 1 日の大半が風速 $2 \mathrm{~m} / \mathrm{s}$ 以下である 7 月 $29 \sim 31$ 日, 8月 2 4日では $N_{e f f}$ は元の標本数 1801 の分の 1 以下に減少して おり，自己相関の考慮によって信頼区間が約1.7 3倍まで増大寸る 結果となった，強風日である 8 月 1 日，日射変化の大きな 8 月 5 日はい ずれも重量が激しく変化しているが，誤差範囲から両者を明確に区 別できることが分かる。7月29 31日, 8月 2,4 日の日中の蒸散速度の 相対誤差 (2標準誤差の比) は平均 $19.8 \%$ (最大 $49.2 \%$ ) となり, 目標の 許容值を満たしていることを確認した。他の供試木の風速 $2 \mathrm{~m} / \mathrm{s}$ 以下 での相対誤差は $4.6 \sim 13.9 \%$ ，全10種の平均值は9.2\%であった。

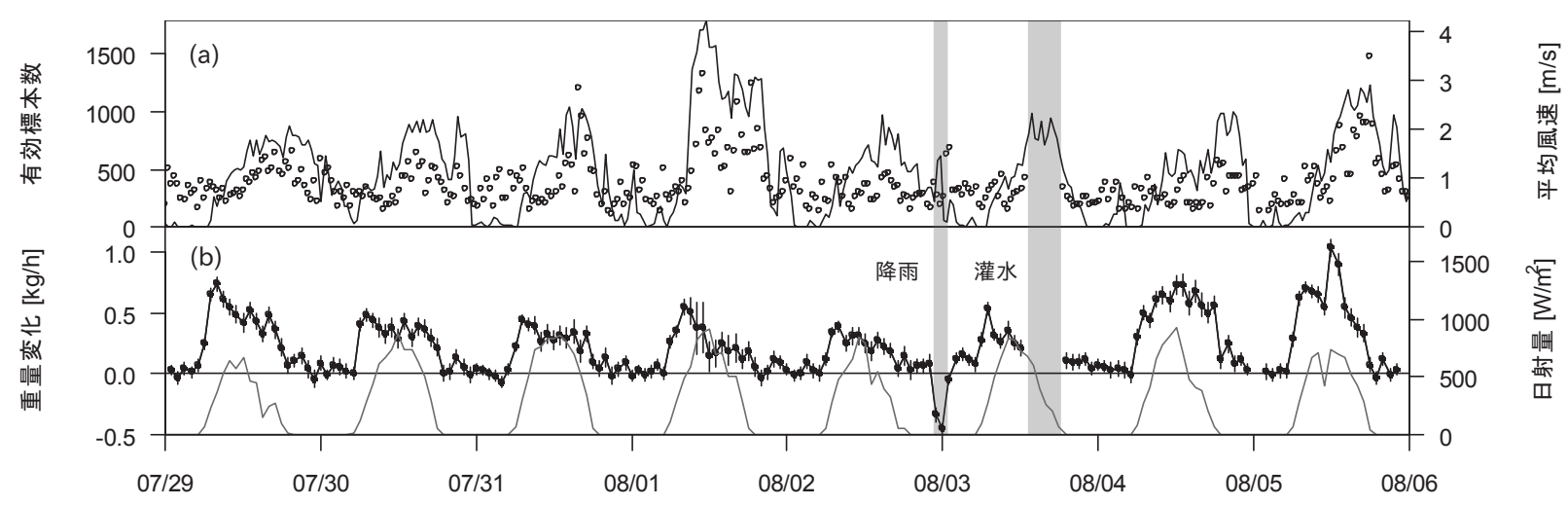

Fig. 6 (a) Half hourly effective sample size of Q.m. (circles) \& wind velocity (line)

(b) hourly weight change (black line) \& short wave radiation $R_{S}$ (gray line) in 2012 (bars: \pm 2 S.E.) 


\section{4. 晴天・灌水日における蒸散量の実測結果}

\section{4-1. 蒸散速度と水蒸気拡散コンダクタンスの日変化}

葉から大気一の水蒸気拡散過程は, 気孔と境界層を直列抵抗とみ なすと次のように表せる30-31).

$$
\begin{gathered}
E_{\text {tree }}=G_{v}\left(e_{l}-e_{a}\right) \\
G_{v}=G_{a} \cdot G_{s} /\left(G_{a}+G_{s}\right)
\end{gathered}
$$

ここで, $E_{\text {tree }}$ : 単木蒸散速度 $[\mathrm{kg} / \mathrm{tree} / \mathrm{h}], G_{v}$ : 単木のバルク水蒸気 拡散コンダクタンス $[\mathrm{kg} / \mathrm{tree} / \mathrm{h}], e_{l} \& e_{a}$ : 葉内平均・大気の水蒸気 分圧 $[\mathrm{kPa} / \mathrm{kPa}], G_{a} \& G_{s}$ : 水蒸気に対する単木のバルク境界層・気 孔コンダクタンス $[\mathrm{kg} / \mathrm{tree} / \mathrm{h}]$ である. 一般に樹木では $G_{a}$ は $G_{s}$ の 5 倍 以上, 特に本研究のように風を受けや寸い孤立環境にある樹木の場 合は 10 倍以上の值を取る ${ }^{30)}$ ， $e_{l}$ は葉温の関数であるが， $G_{a}$ が大きい （即ち対流熱伝達率が大きい）樹木では樹冠平均温度は気温に近づ くため, $E_{\text {tree }} \approx G_{v} D(D:$ : 気の実際の水蒸気分圧と飽和水蒸気分圧 の差) と近似できる ${ }^{31)}$. 2012年の計測期間中に赤外線放射カメラの

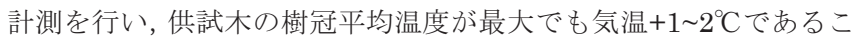
とを確認した上で, $E_{\text {tree }} \approx G_{v} D$ と仮定して $G_{v}$ を計算した注4).

図7に比較的風速の安定した, 典型的な晴天・灌水日における各樹 種の $E_{\text {tree }}$ と $G_{v}$ の日変化を示す. なお, 重量データが|歪度 $\mid>1$ まは 尖度 $>6$ となった条件については $E_{\text {tree }}$ を白抜きのプロットで表す. 全 供試木での $E_{\text {tree }}$ の最大值はケヤキ2010年, コナラの約 $3.5 \mathrm{~kg} / \mathrm{tree} / \mathrm{h}$ となった。これは潜熱量 $2.3 \mathrm{~kW}$, 家庭用エアコン 1 台分の冷房能力に

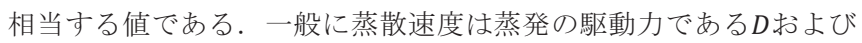
その要因となる気温の変化に連動することが知られ, 本研究でも $E_{\text {tree }}$ のピークは多くの個体で13 14時頃に表れていた。 しかし, ソ メイヨシノ, イチョウ, ヤマボウシは午前中にピークを持ち日中横 ばいに近い変化を示していた。これらの供試木では水ポテンシャル 低下による通水制限21) 32) が起きていた可能性が考えられる. 蒸散流 (樹液流) 速度は土壌〜葉の水ポテンシャル勾配に比例するが，葉の 側で低下可能な水ポテンシャルには一定の限界 (温帯広葉樹では約 -1.5 - 2.5MPa) があるため, 通水制限下では $G_{s}$ は水ポテンシャルが 限界值以下に下がらないよう（即ち蒸散速度が一定以上にならない よう)に制御される。通水性は葉と根の面積比で決まる32) ため, ソ メイヨシノ, イチョウ, ヤマボウシはコンテナによって根の生長が 阻害され葉と根のバランスが崩れていた可能性が考えられる.

$G_{v}$ はケヤキ 2010 年以外の全ての供試木において朝6 8時頃に明確 なピークを持ち， $E_{\text {tree }}$ の増大に応じるように日中低下 (Midday depression, 昼寝現象) していた. $G_{v}$ の日中低下は孔辺細胞が蒸散速 度の増大を感知することによる $G_{s}$ のフィードバック的応答 ${ }^{33)}$, また は昼の強い日射による強光阻害・高温による酵素不活性化を要因と する光合成速度低下による $G_{s}$ のフィードフォワード的応答 ${ }^{34)}$ によ って引き起こされる. 従って日中低下が明確でないケヤキ2010年, シラカシ 2013 年, コナラの3個体は乾燥・光・熱ストレスを比較的受 けておらず, そのために $E_{\text {tree }}$ の值も他の個体より大きくなったもの と考えられる。

日積算蒸散量はケヤキ 2010 年，コナラ，クスノキが約 $30 \mathrm{~kg} / \mathrm{tree} / \mathrm{d}$ と最も多く, 次いでケヤキ2012年, シラカシ 2013 年, クヌギが約 $25 \mathrm{~kg} / \mathrm{tree} / \mathrm{d}$ なった。一方, 少ないものではシラカシ2012年, エゴ ノキが $10 \mathrm{~kg} / \mathrm{tree} / \mathrm{d}$ 程度となり, ケヤキとシラカシでは蒸散特性に大 きな経年変化が生じていた。

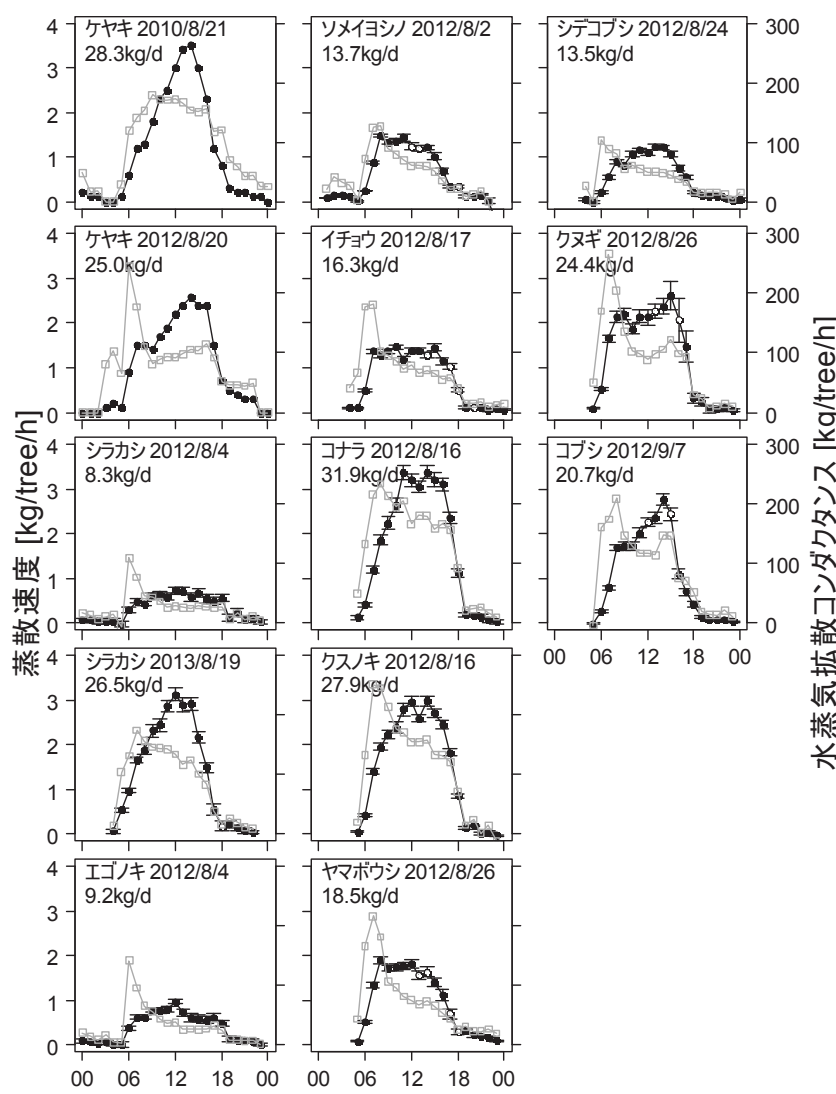

Fig. 7 Diurnal change of whole tree transpiration rate $E_{\text {tree }}$ (black line) \& vapor diffusion conductance $G_{v}$ (gray line) in sunny irrigation day (white circles indicate absolute value of skewness $>1$ or kurtosis $>6$, bars: \pm 2 S.E.)

シラカシは外形に目立った変化が見られなかったにも関わらず 2012 2013年にかけて日蒸散量は約3倍に増大していた。この特性 変化の原因として，2012年に図2中央部の植栽群内から図に示した 孤立環境に移動させたことで光環境が改善し, 光合成能力が増大し た可能性が挙げられる. 2012年の実測前に配置を変えていたにも関 わらず当時は $E_{\text {tree }}$ が小さかった理由として, シラカシの葉の寿命が 36 月あるために光合成能力の増大 (新たな環境下での着葉) に時 間がかかったことが考えられる注 5$)$.また根の生長には一般的には数 週〜数か月程度かかる ${ }^{32)}$ ため, 日射環境の変化に対して通水性の変 化が追い付いていなかった可能性もある.

ケヤキの葉面積は2010 2012年にかけて $15.4 \mathrm{~m}^{2}$ から $28.9 \mathrm{~m}^{2}$ に倍 増していたにも関わらず $G_{v}$ は約 $2 / 3$ に減少し, 葉面積あたりの蒸散速 度は $1 / 2 \sim 1 / 3$ まで減少する結果となった. これは単木の通水性が変化 しなかったことの影響と考えられる。即ち，蒸散速度は土壌から葉 までの通水コンダクタンスに比例する21) 32$)$ ために， $0.5 \mathrm{~m}^{3}$ の土壤容 積や約 $10 \mathrm{~cm}$ の生枝下直径という条件では $30 \mathrm{~kg} / \mathrm{tree} / \mathrm{d}$ 程度の蒸散量 が限界であり，葉面積の増大が蒸散速度の増大に繋がらなかったも のと考えられる．2章で述べたように 2010 年当時は枝打ちによって 葉面積が減少していたために単位葉面積当たりの通水性が過剩であ ったと考えられ，ケヤキ 2010 年の $G_{v}$ が日中に横ばいとなる (気孔閉 鎖が不明瞭な) 変化パターンはこの仮説を支持するものである.類似 した現象として, 既往研究ではOren et al. (1999)が竜巻被害を受け た針葉樹林において，葉面積が $55 \%$ に減少したものの樹液流は $80 \%$ 

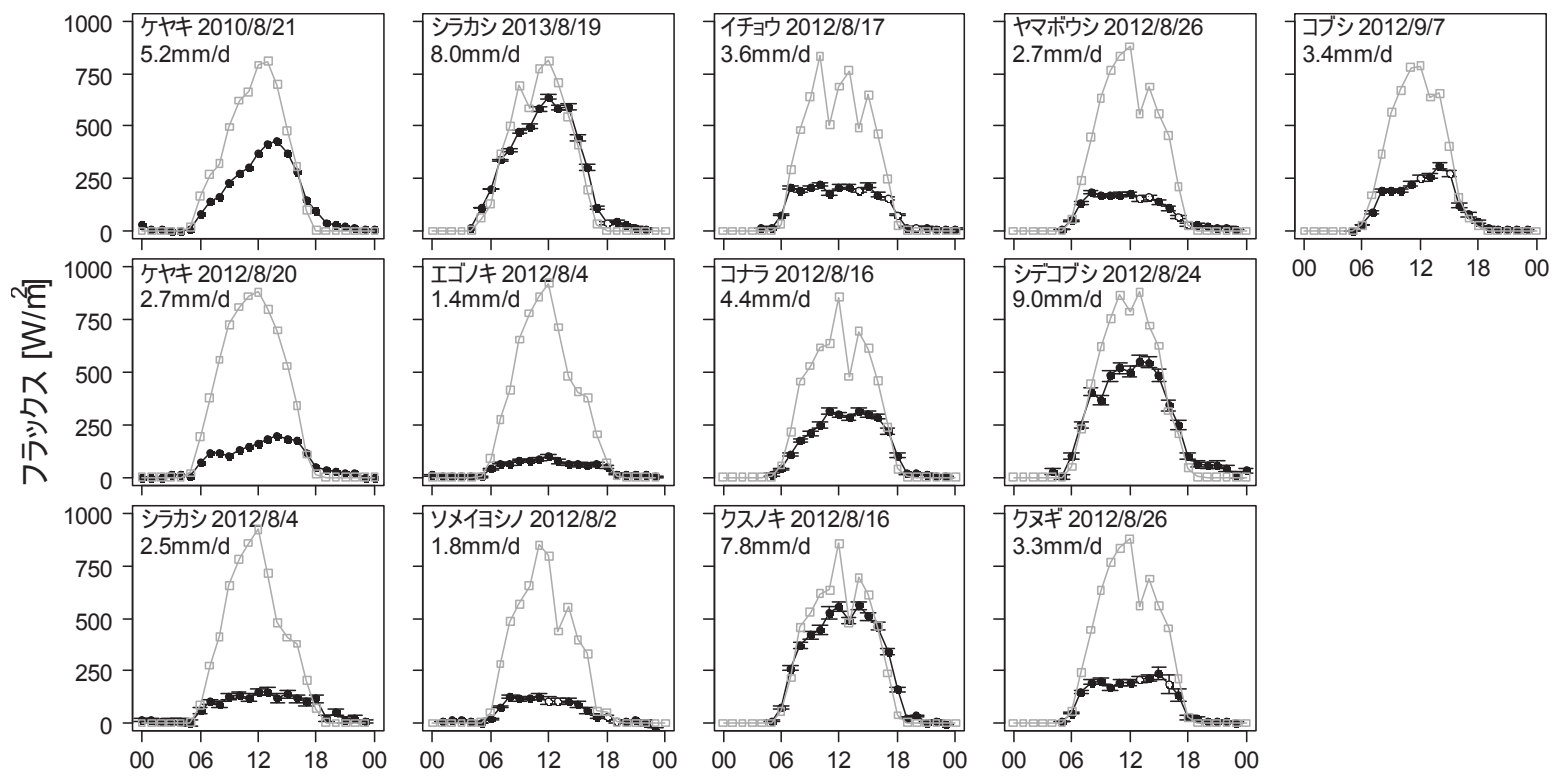

Fig. 8 Diurnal change of latent heat $\lambda E_{c r}$ (black line) \& short wave radiation $R_{s}$ (gray line) in sunny irrigation day, based on crown projection area (white circles indicate absolute value of skewness $>1$ or kurtosis $>6$, bars: \pm 2 S.E.)

程度の值を維持していたことを報告している5

\section{4-2. 樹冠投影面積あたりの潜熱量}

図8に供試木の樹冠投影面積あたりの潜熱量 $\lambda E_{c r}$ と水平面全天日 射量 $R_{S}$ の日変化を示寸. なお, シラカシ 2013 年は幹直径に変化が見 られなかったことから2012年と同サイズと仮定して計算した ${ }^{35)}$.イ チョウやクスノキでは $\lambda E_{c r}$ が $R_{s}$ の短時間変化に連動している様子が 見られ, 本研究の提案する吊り下げ法が1時間単位での蒸散速度変 化を正確に捉えていることがわかる． $\lambda E_{c r}$ の大きなものとして，投 影面積の小さなシラカシ2013年，クスノキ，シデコブシの3個体は 最大 $500 \mathrm{~W} / \mathrm{m}^{2}$ を超えていた. ただしシデコブシについては単木蒸散 速度 $\left(E_{\text {tree }}\right)$ は他と比べて小さい部類であった（図7）。シラカシ2013 年とクスノキの $\lambda E_{c r}$ は一日を通して $R_{s}$ とほぼ同等の值を取ってお り，葉面積密度(LAD)や個葉単位での蒸散速度，またはその双方が 他の供試木より大きいものと判断できる. 一方で $\lambda E_{c r}$ が小さなエゴ ノキとソメイヨシノは最大約 $100 \mathrm{~W} / \mathrm{m}^{2}$ であり，ピーク值には約 5 倍 の個体差が見られた。

既往研究では孤立環境にある樹木が群落より多く蒸散する可能性 が指摘されている16-17) が，本研究の結果では過半数の供試木の潜熱 ピーク值が $300 \mathrm{~W} / \mathrm{m}^{2}$ 以下と, 標準的な温帯広葉樹林並みの值であっ た. 孤立樹木は側面から受ける日射量も大きいため, 実際の吸収日 射量と潜熱量の比はさらに小さくなるものと考えられる. 図 7 ・8は 典型的な夏季晴天日かつ十分な灌水条件の結果であるため, 蒸散速 度の制限要因としてはコンテナに限定された土壌容積による根系の 発達阻害がボトルネックとなっていた可能性がある。乾燥ストレス の影響が顕著でないケヤキ 2010 年の潜熱量は日射量の $50 \%$ 以上に 達し, 単位片面葉面積あたりでは最大 $153 \mathrm{~W} / \mathrm{m}^{2}(0.23 \mathrm{~mm} / \mathrm{h})$, 日中 平均 $91 \mathrm{~W} / \mathrm{m}^{2}(0.13 \mathrm{~mm} / \mathrm{h})$ となった. 葉面積の増大後のケヤキ 2012 年 の潜熱量は単位片面葉面積あたり最大 $62 \mathrm{~W} / \mathrm{m}^{2}(0.09 \mathrm{~mm} / \mathrm{h})$, 日中平 均 $44 \mathrm{~W} / \mathrm{m}^{2}(0.07 \mathrm{~mm} / \mathrm{h})$ であった。

本研究の供試木の投影面積あたり日蒸散量の範囲は $4.3 \pm 2.5$ $\mathrm{mm} / \mathrm{d}\left(\right.$ Mean \pm S.D., 以下同様) となった. コンテナ植栽の既往研究 $\left.{ }^{27}\right)$
と比較して妥当な範囲と考えられるが，建築環境工学分野でしばし ば参考とされるCASBEE-HIの作成時において参考值とされた ${ }^{12}$, イチョウとプラタナスの切断葉の重量変化 (蒸散速度)計測に基づく 推定值 $14.9 \pm 6.4 \mathrm{~mm} / \mathrm{d}$ よびケヤキが芝生の 12 倍以上蒸散するとい う野島(1998)の計算結果13) に比較して小さな值である. 文献12)の参 考値との差異について, まず, 切断葉から蒸散速度を推定する手法 に関しては，切断葉と自然状態そのままでの計測では放射環境が異 なり，葉温と気孔開度はいずれも数分で容易に変化するために蒸散 速度も変わる可能性が高いことから，この手法による推定精度の問 題が一因として挙げられる注6). 次に, 野島(1998)との差異について, 野島(1998)は供試木のケヤキの葉面積指数(LAI)を8.8 と推定しポロ メーター計測に基づく個葉の蒸散量予測式から単木蒝散量を求めて 芝生と比較している。しかし，LAI 8.8 という值は夏季の一般的な落 葉広葉樹の2倍近い值であり14-15)，更に野島(1998)はMonsi \& Saeki 式36) $\left(I=I_{0} \exp (-k F) I\right.$ : 葉群層内の水平面日射量, $I_{0}$ :キャノピー上 の水平面日射量, $k$ :吸光係数, $F$ :積算葉面積指数) から計算した各葉 群層内の水平面日射量 $I$ の值を葉の吸収日射量とみなして蒸散速度 を計算している. しかし，吸光係数は主に葉の傾きを表すパラメー タであり，実際に葉が吸収する日射量は- $d I / d F=k I_{0} \exp (-k F)=$ $k I$ となるため, 水平面日射量 $I$ よりも小さな值を取る。つまり，野島 （1998）では標準的な広葉樹に比べて大きな葉面積と多大な日射吸収 量を想定した計算が行われていたために，本研究より大きな值を取 ったものと考えられる.

本研究に類似したサイズ，環境条件（日積算日射量約 $20 \mathrm{MJ} / \mathrm{d}$ ，孤 立環境，湿潤土袞）の地植えの樹木を対象に樹液流計測を行った既 往研究として, Green(1993), Green et al.(2002)がある10-11)。日積算 值では樹液流速と蒸散速度の時間差の影響が無視できるため，ここ では1日以上の単位で議論する注7). Green (1993)はニュージーラン ドの戋場 $\left(40^{\circ} 2^{\prime} \mathrm{S}, 175^{\circ} 4^{\prime} \mathrm{E}\right)$ において, 孤立環境にある地植えのクル ミ(樹高 $3.5 \mathrm{~m}$, 葉面積 $26.4 \mathrm{~m}^{2}$ ) を対象に夏季の単木の正味放射量の直 接計測と樹液流計測を行い, 晴天日における日蒸散量が $40 \mathrm{~kg} / \mathrm{tree} / \mathrm{d}$ 
（投影面積あたり約 $4.9 \mathrm{~mm} / \mathrm{d}$ ) であったこと, 日中の潜熱量が正味放 射量の約2/3であったことを報告している11). またGreen et al.(2002)

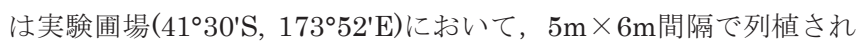
たオリーブ（樹高約 $4 \mathrm{~m}$, 葉面積 $13.5 \mathrm{~m}^{2}$ ) を対象に樹液流計測を行い, 夏季における蒸散量が最大 $175 \mathrm{~kg} / \mathrm{tree} / \mathrm{wk} ゙$ あったことを報告して いる10). 対象樹種や詳細条件は異なるが, 本研究において蒝散量が 多く見られた供試木（ケヤキ, コナラ等）は地植えの樹木を対象と したGreen (1993), Green et al. (2002)の報告と近い值を取っていた ことから, これらの供試木では土壌容積の制限による影響が (ソメ イヨシノ，イチョウ等と比較して）小さかったことが推測される.

\section{4-3. 日蒸散量と形態的・生理的特徵の関係}

本節では蒸散の気象条件への依存性を考慮して, 小水面の日蒸発 量を表すMakkink式 $37-38)$ による可能蒸発量 $\left(E_{\text {pot }}\right)$ を用いて日中 $\left(R_{S}>0\right) の$ 積算蒸散量を無次元化した上で分析を行った.

$$
E_{\text {pot }}=a \frac{s}{s+\gamma} \frac{R_{s}}{\lambda}+b
$$

ここで, $E_{p o t}$ : 可能蒸発量 $[\mathrm{mm} / \mathrm{d}], s:$ 気温での飽和水蒸気圧曲線の 傾き, $\gamma$ : 乾湿計定数, $\lambda$ : 蒸発潜熱, $a \& b$ : 地域ごとの経験的定 数である(ここでは温帯の標準值 ${ }^{38)} a=0.97, b=-0.29$ を用いる).

Penman式の簡易版である(7)式は気温と日射量だけを入力条件 とするためにより多くの過去のデータが利用可能であり, 多くの標 本数を必要とする比較分析を行う際の利点が大きい. 本研究では森 林の既往研究との比較のために(7)式を用いる. また水文気象学分野 では土地 (樹冠投影) 面積基準で蒸散量を求めることが多いが, 本研 究ではそれに加えて対象が孤立樹木であることを鑑みて, 単木単位 の蒸散能力を表すための $1 \mathrm{~m}^{2}$ で基準化した值も算定した (コンテナ 占有面積での基準化ともみなせる值である).ここではそれぞれの可 能蒸発量比を $E_{c r} / E_{p o t}, E_{t r e e} / E_{p o t}$ と表す.

図9に夏季晴天・灌水日における供試木の蒸散量計測值から得た $E_{c r} / E_{p o t}, E_{\text {tree }} / E_{\text {pot }}$ の值を示す. 蒸散特性に大きな変化があったケ ヤキ (2010年と 2012 年) とシラカシ (2012年と 2013年)を別個体とみ な寸と, $E_{c r} / E_{\text {pot }}$ の平均値と標準偏差は $0.62 \pm 0.36(\mathrm{n}=13$, Range: 0.19-1.25) となった.この結果は供試木の平均蒸散量が樹冠投影面 積と等しい広さの水面からの蒸発量の 6 割程度であること, 投影面 積基準では個体によって約6倍の蒸散能力の差があることを意味す る. 水面より小さい值を取るのは気孔制御のためであり, 一般に夏 季の植生の蒸散が水面蒸発量を超えることは稀であるが，本研究で はシラカシ2013年とクスノキがそれぞれ $1.25 ， 1.20$ という值を示し た。これはLADの大きさと, 孤立樹木であることによる側面からの 日射と移流効果17)が影響したものと考えられる.

Komatsu (2005)は成長期かつ湿潤期の森林における日中の蒸発 散量の文献值を森林の特徴ごとにまとめている15)。この文献值を基 に(7)式から温帯広葉樹林の $E_{c r} / E_{p o t}$ を計算すると, $0.65 \pm 0.13$ (n=14, Range：0.46-0.84)であった. 平均值は本研究と有意な差が あるとは言えないが, 標準偏差は本研究の方が大きく最大・最小值 も本研究の方が広い範囲を取っていた. Komatsu (2005)に引用され ている広葉樹林の特徴は幅広く偏りは見られない(例えばLAI範囲 は3.3 7である)ため, 本研究で得られた結果との比較から, (1)孤立 環境(強い日射と小さな境界層抵抗) とコンテナ植栽 (根系の生長阻 害) という条件が樹種あるいは個体に固有の特性を際立たせること,

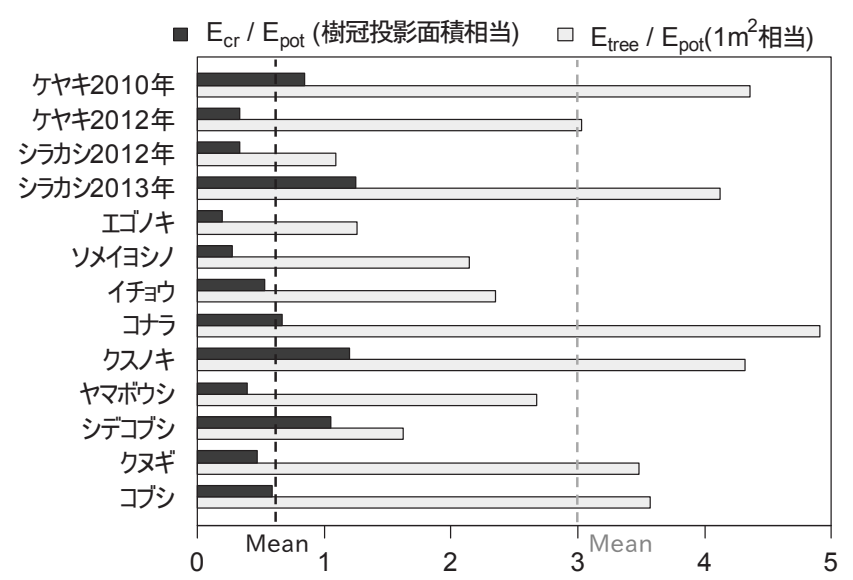

Fig. 9 Standardized daily transpiration rate $E_{c r} / E_{\text {pot }} \& E_{\text {tree }} / E_{\text {pot }}$, dashed lines indicate mean values

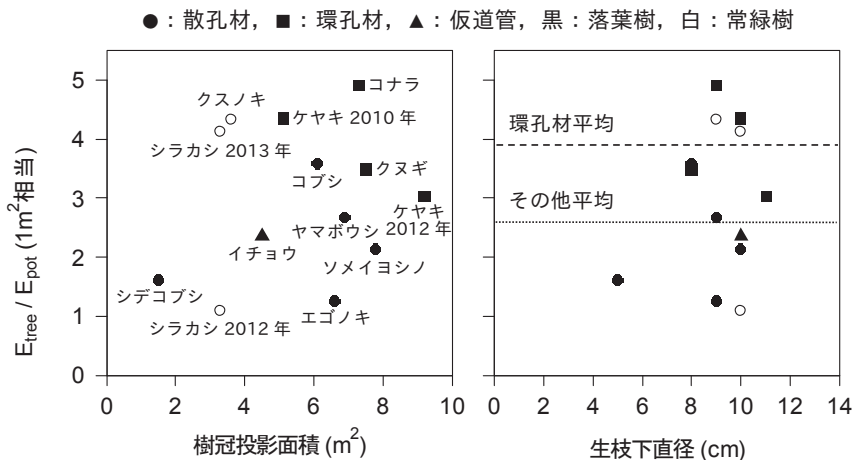

Fig. 10 Relationships between $E_{\text {tree }} / E_{\text {pot }}$ \& morpho-physiological characteristics of sample trees

(2)樹種あるいは個体ごとの乾燥ストレス而性には大きな差がある こと, (3)都市緑化樹木の単木スケールの蒸散量を予測するには森林 以上に詳細なモデル・パラメータが要求されることが示唆される.

図10 亿供試木の形態的・生理的特徵と $E_{\text {tree }} / E_{\text {pot }}$ の関係を示す. $E_{\text {tree }} / E_{\text {pot }}$ の平均值と標準偏差は 3.00土1.26 ( $\mathrm{n}=13$, Range: 1.09 -4.91) となった。単木蒸散量は葉面積と, 葉面積は幹の太さと ${ }^{35)}$ そ れぞれ相関があるために, 樹冠投影面積や幹直径に伴う蒸散量の増 大が期待されたが，本研究では有意な影響は確認されなかった。本 研究の供試木程度のサイズ差では投影面積・幹直径の蒸散量への影 響は小さく,樹木形状を基に蒸散量を予測するためには, LAIやLAD のような, より高精度な形態情報が必要と考えられる。また個葉計 測の既往研究では夏季において落葉樹が常緑樹より蒸散速度が大き い傾向が報告されている23) が，これも本研究の結果からは確認され なかった。

通水性に影響する道管種の違いに着目すると, 太い道管を持つ環 孔材樹種であるケヤキ2010年・2012年, コナラ, クヌギは蒸散量が 多い傾向が見られた（環孔材平均 3.94 , その他 $2.57, \mathrm{p}=0.045$ in Welch's t-test). 本研究と類似した傾向を示した既往研究として, Saito et al. (2003) は山梨県内の実験圃場において落葉広葉樹8種 (うち3種はケヤキ, コナラ, コブシ)の個葉の蒸散速度を計測し, ケ ヤキとコナラの值が最も大きかったことを報告している39). ただし 本研究の結果から環孔材樹種は一般的に蒸散量が大きいとは断言で 
きない. 都市緑化樹木を対象に道管種別の樹液流速を調べたLitvak et al. (2012)は, 環孔材樹種は他に比べ乾燥ストレスに敏感な傾向 を報告している9)。本研究の供試木は毎日灌水された条件で生育し ており，都市の樹木に比べて乾燥に鈍感な特性を持っていた可能性 がある. しかし同時に, 十分に灌水されていれば水供給能力に優れ る環孔材樹種がより多く蒸散する可能性も考えられる.

\section{5. 結論}

大型重量計による単木スケールの蒸散量の計測手法を提案し, 孤 立環境にあるコンテナ植栽（土壌容積 $0.5 \mathrm{~m}^{3}$ ) の樹木 11 種の夏季晴 天・灌水日における蒸散量の計測を行い, 以下を明らかにした.

1）提案した吊り下げ式計測法が蒸散速度の1時間単位の日射応答 および気孔の日中低下を確認できる精度を持っていることを示 した，高分解能の記録と自己相関を考慮した分析によって，風 速 $2 \mathrm{~m} / \mathrm{s}$ 以下の条件では, 最も蒸散量の少ないシラカシ (2012年) の日中の蒸散速度を相対誤差 (2標準誤差) $19.8 \%$ で, 全 10 種の平 均では $9.2 \%$ で推定できることを示した。

2）供試木の蒸散量の日積算值は約 10 30kg/tree となり，3倍以上の 個体差が見られた. 単木あたりでの最大蒸散速度はケヤキ $(2010$ 年) とコナラの $3.5 \mathrm{~kg} / \mathrm{tree} / \mathrm{h}$, 潜熱量 $2.3 \mathrm{~kW} /$ treeであった。 また 水蒸気拡散コンダクタンスの変化傾向から, この2個体は乾燥・ 光・熱ストレスを比較的受けていなかった可能性が高いことを 示した。

3）樹冠投影面積あたりの潜熱のピーク值は過半数の供試木では $300 \mathrm{~W} / \mathrm{m}^{2}$ 以下，樹冠投影面積の小さなシラカシ (2013年), クス ノキ, シデコブシでは $500 \mathrm{~W} / \mathrm{m}^{2}$ 以上となり, 5 倍以上の個体差が 見られた。

4）ケヤキは 2010 年から 2012 年で葉面積が $15.4 \mathrm{~m}^{2}$ から $28.9 \mathrm{~m}^{2}$ に倍 増したが，単位片面葉面積あたりの潜熱量は日中平均 $91 \mathrm{~W} / \mathrm{m}^{2}$ から $44 \mathrm{~W} / \mathrm{m}^{2}$ と $1 / 2$ 以下に減少していた。コンテナ植栽では通水 性が単木の蒸散速度の支配的要因である可能性を示した。

5）シラカシは2012年から 2013 年で 3 倍以上の蒸散量の変化が確認 された．要因として，2012年の計測前の配置移動による日射環 境の変化の影響が推測された。

6）経年変化後のケヤキとシラカシを別個体とみなした場合，樹冠 投影面積あたりの日蒸散量の可能蒸発量との比は $0.62 \pm 0.36$ (Mean \pm S.D., n=13) となった. また, 既往研究の温帯広葉樹林 の值は $0.65 \pm 0.13(\mathrm{n}=14)$ となり, 平均值に有意な差はみられなか ったが, 標準偏差および最大・最小值は本研究の方がより広い 範囲を取っていた。

7）可能蒸発量比と樹木の形態的・生理的特徵の相関からは, 樹冠 投影面積, 生枝下直径, 葉齢については有意な影響は確認され なかった. 道管種については環孔材樹種の蒸散量が多い可能性 が示唆された( $=0.045$ in Welch's t-test).

1時間単位での蒸散速度の予測や, 樹木サイズ・形状の影響を分析 するためには, 計測した単木の蒸散速度から単位葉面積あたりのコ ンダクタンスを算定し, 更に気孔の環境応答を定量化することが必 要である. 本研究の供試木に対しては2012年にレーザースキャナー
による3次元形態情報の計測を行っており，今後はLAI・LADを用い た単位葉面積あたりの潜熱量の算出と, 気孔コンダクタンスパラメ ータの定量化に取り組んでいく予定である.ただし, 本研究中でも 示されたように, 葉面積の増大が蒸散量の増大に直結しないことは 土壌容積が制限された都市緑化樹木の大きな特徵と考えられるため, 樹木サイズの外挿には慎重な検討が必要である.

ヒートアイランド化の進んだ都市環境にある樹木は, 大気の乾燥, 土壌容積の制限，土壌の乾燥等の水分不足に陥りやすい条件に置か れていると考えられるため, 気孔コンダクタンスの乾燥ストレスに 対する知見を深めることは特に重要な課題である. 本研究の灌水停 止実験結果についても，今後分析を進めていく.

注

注1）例えばLeverenz et al. (1982)は，トウヒ林の水蒸気拡散コンダクタンス を個葉計測から相対誤差 ( $95 \%$ 信頼区間) $10 \%$ 以下で求めるためには，少 なくとも 155 以上の標本数が必要であることを示している6).

注2）国土交通省土木工事積算基準40) では, 幹直径 8 9.5 cmの樹木に対する土 壤容積は $0.65 \mathrm{~m}^{3}$ が目安とされている. 土袞梁さについては, 森林・都市 いずれの環境においても樹木の細根は80 90\%が土壌深さ $40 \mathrm{~cm}$ までの 表層部に集中している41) ため, 一般的な条件と大きく変わらないものと 考えられる. なお, 本研究の供試木の土壌容積は造園の専門化の助言に 従って決定している。

注3）ここで相対誤差の許容值を $20 \%$ と定めたのは, 一般的な植生のフラック スインバランス率42)や, 針葉樹閉鎖林における樹液流法を用いた林分蒸 散量推定の際の個体差による変動係数43) が2割程度であることから, 本 研究の実験環境の影響や供試木間の特性の違いを比較する上で最低限 必要な精度と考えられるためである。

注4）葉温の上昇しやすい（葉が大きく蒸散速度の小さい）供試木では， $G_{v}$ の 日中低下が図 7 の計算值より急激であった可能性がある。気温 $33^{\circ} \mathrm{C}$ ，水 蒸気圧 $2.4 \mathrm{kPa}$ の環境（葉温と気温の差が最大となる昼過ぎの条件）にお いて葉温が $35^{\circ} \mathrm{C}$ の場合, 葉温を気温相当と夕なすこことにる水蒸気拡散 コンダクタンスの推定誤差は約 $22 \%$ となる。なお，単木スケールの正味 放射量と刘流熱伝達率の正確な計測が困難な現状では，第一次近似とし て葉温を気温相当とみなすことは森林水文学等の分野でも一般的であ る.

注5) 成熟した葉であっても光環境の改善に対応して数日程度で光合成能力 は増大（光順化）するが, 初めから良好な光環境で着葉したものに比心゙ ると劣る場合が多いことが知られる。

注6）熱帯樹木 10 種の切断葉のガス交換速度変化を調べたSantiago \& Mulkey (2003)は，切断後 3 分で $40 \%$ に低下したものから 1 時間後も $86.5 \%$ を維持 していたものまで大きな差があったことを報告しており ${ }^{44)}$ ，樹種の違い についても自然状態とは異なる可能性がある。

注7) Green (1993), Green et al. (2002)は樹液流法によって䓠散量を推定して いるが，以下の理由からデータの信頼性は高いと考えられる。(1)日単位 の推定では樹液流速と蒸散速度の時間差による誤差が無視できる. (2)Green et al. (2002)の供試木であるオリーブについては,重量計による 蒸散量計測值を基にセンサーの較正が行われている. (3)Green (1993)で は一本の供試木に対して高さ 3 点・長さ $0.5 \sim 4.8 \mathrm{~cm}$ のセンサー 4 種（計 12 箇所）で計測を行っており，幹内の流速分布が考慮されている. (4)セン サー設置のために幹に付けた傷の影響の補正2)が行われている。(5) Green (1993), Green et al. (2002)で用いられているヒートパルス法は (基淮温度との差を測るGranier法と異なり) パルスの移流速度を測る 方式であるため日射等の影響を受けにくい，

\section{参考文献}

1) Granier A.: Evaluation of transpiration in a Douglas-fir stand by means of sap flow measurements, Tree Physiol., Vol.3, Issue 4, pp.309320,1987

2) Swanson R.H., Whitfield D.W.A.: A numerical analysis of heat pulse velocity and theory and practice, J. Exp. Bot., Vol.32, No.126, pp.221$239,1981.2$

3) Steppe K., De Pauw D.J.W., Doody T.M., Teskey R.O.: A comparison of 
sap flux density using thermal dissipation, heat pulse velocity and heat field deformation methods, Agric. For. Met., Vol.150, Issue 7-8, 2010.7

4) Saugier B., Granier A., Pontailler J.Y., Dufrene E., Baldocchi D.D.: Transpiration of a boreal pine forest measured by branch bag, sap flow and micrometeorological methods, Tree Physiol., Vol17, Issue 8-9, pp.511-519, 1997

5) Oren R., Phillips N., Ewers B.E., Pataki D.E., Megonigal J.P.: Sap-fluxscaled transpiration responses to light, vapor pressure deficit, and leaf area reduction in a flooded Taxodium distichum forest, Tree Physiol., Vol.19, Issue 6, pp.337-347, 1999

6) Leverenz J., Deans J.D., Ford E.D., Jarvis P.D., Milne R., Whitehead D.: Systematic spatial variation of stomatal conductance in a sitka spruce plantation, J. Appl. Ecol., Vol.19, No.3, pp.835-851, 1982.12

7）浅輪貴史, 梅干野脂, 清水克哉, 久保田光政 : 大型重量計を用いた単木樹 木の蒸散量の計測法とその精度確認, 日本緑化工学会誌, 第 38 巻 1 号, pp.67-72, 2012.8

8）浅輪貴史, 梅干野毾, 清水克哉, 久保田光政: 大型重量計を用いた夏季に おけるケヤキ単木の蒸散特性の分析, 日本緑化工学会誌, 第 39 巻 4 号, pp.534-541, 2014.5

9) Litvak E., McCarthy H.R., Pataki D.: Transpiration sensitivity of urban trees in a semi-arid climate is constrained by xylem vulnerability to cavitation, Tree Physiol., Vol.32, Issue 4, pp.373-388, 2012

10) Green S., Clothier B., Caspari H., Neal S.: Root-zone processes, tree water use and equitable allocation of irrigation water to olives, $\mathrm{Am}$. Geophys. Union, 129, pp.337-345, 2002

11) Green S.R.: Radiation balance, transpiration and photosynthesis of an isolated tree, Agric. For. Met., Vol.64, Issue 3-4, pp.201-221, 1993.5

12) 手代木純, 興水肇: CASBEE-HI作成過程における緑の環境改善効果をめ ぐる論点，ランドスケープ研究，第74巻5号, pp.721-726, 2011

13）野島義照: 都市における植生からの蒸散による夏季の温熱環境改善力に 関する研究，京都大学博士論文，pp.145，1998

14) 近藤純正 : 種々の植生地における蒸発散量の降水量および葉面積指数一 の依存性，水文・水資源学会誌，第11巻7号，pp.679-693，1998

15) Komatsu H.: Forest categorization according to dry-canopy evaporation rates in the growing season: comparison of the PriestleyTaylor coefficient values from various observation sites, Hydrol. Process, Vol.19, Issue 19, pp.3873-3896, 2005.11

16）森脇亮, 神田学 : 都市接地層における放射・熱・水・ $\mathrm{CO}_{2}$ フラックスの長 期連続観測，水文・水資源学会誌，第 16 巻 5 号，pp.477-490，2003

17) 成田健一, 萩島理, 谷本潤, 高野武 : 都市域における樹木の蒸散特性 : オ アシス効果に関する野外実験, 日本建築学会環境系論文集, 第608号, pp.59-66, 2006.10

18) Niklas K.J.: Modelling below- and above-ground biomass for nonwoody and woody plants, Ann. Bot., 95(2), pp.315-521, 2005

19）山村真司，梅干野昆，浅輪貴史 : 建築外部空間デザインの設計支援を目的 とした熱収支・気流連成シミュレーション手法開発の基礎的検討, 日本建 築学会計画系論文集, 第560号, pp.73-80, 2002.10

20）国土技術政策総合研究所 緑化生態研究室：わが国の街路樹VI, 国総研資 料, Vol.506, 2009.1

21）Tyree M., Zimmermann M. (著)，内海泰弘，古賀信也，梅林利弘（訳）： 植物の木部構造と水移動様式，丸善出版，2007

22) Wright I.J., Reich P.B. et al.: The worldwide leaf economics spectrum, Nature, Vol.428, pp.821-827, 2004.4

23) Kosugi Y., Shibata S., Matsui K., Kobashi S.: Differences between deciduous and evergreen broad-leaved trees in the pattern of seasonal change of leaf-scale photosynthetic net assimilation rate and transpiration rate, J. Jap. Soc. Reveget. Tech., Vol.22, No.4, pp.205-215, 1997.2

24) Niinemets U., Valladares F.: Tolerance to shade, drought, and water logging of temperate northern hemisphere trees and shrubs, Ecol. Monogr., Vol.76, Issue 4, pp.521-547, 2006.11

25) Asawa T., Hoyano A., Oshio H., Honda Y., Shimizu K., Kubota M.: Terrestrial LiDAR-based estimation of the leaf area density distribution of an individual tree and verification of its accuracy, Int. Symp. on Remote Sens., 2014（電子プロシーディングス）
26) $R$ Development Core Team: $R$ : A language and environment for statistical computing, R Foundation for Statistical Computing, Vienna, Austria, 2014.10, URL http://www.R-project.org., 2015.4.3参照

27) 吉田弘, 瑞野道夫 : 大型ウェイングライシメータによる林木蒸散量計測の 試み，水工学論文集，第43巻，pp.67-72，1999.2

28) Trenberth K.E.: Some effects of finite sample size and persistence on meteorological statistics Part I: autocorrelations, Mon. Weather Rev. Vol.112, Issue 12, pp.2359-2368, 1984.12

29）伊藤久徳，見延庄士郎（著），気象研究ノート編集委員会（編）：気象研究 ノート第 221 号 気象学と海洋物理学で用いられるデータ解析法, 日本気 象学会, 2010

30) Jones H.G.: Plants and Microclimate $2^{\text {nd }}$ ed., Cambridge University Press, 1992

31) Oke T.R.: Boundary Layer Climates $2^{\text {nd }}$ ed., Routledge, 1987

32 ) 谷享 (著): 植物の水利用: 明るい環境では根を増やすわけ，種生物学会 (編): 光と水と植物のかたち 植物生理生態学入門, 文一総合出版, pp.141-161, 2003

33) Mott K.A., Parkhurst D.F.: Stomatal responses to humidity in air and helox, Plant, Cell \& Environ., Vol.14, Issue 5, pp.509-515, 1991.6

34) Duursma R.A., Barton C.V.M., Lin Y-S., Medlyn B.E., Derek E., Tissue D.T., Ellsworth D.S., McMurtrie R.E.: The peaked response of transpiration rate to vapour pressure deficit in field conditions can be explained by the temperature optimum of photosynthesis, Agric. For. Met., Vol.189-190, pp.2-10, 2014.6

35) Shinozaki K., Yoda K., Hozumi K., Kira T.: A quantitative analysis of plant form-The pipe model theory 1. Basic analysis, J. Jour. Ecol., Vol.14, No.3, pp.97-105, 1964.6

36) Monsi M., Saeki T.: Über den Lichtfaktor in den Pflanzengesellschaften und seine Bedeutung für die Stoffproduktion, Jap. J. Bot., Vol.14, pp.22-52, 1953

37) Makkink G.F.: Ekzameno de la formula de Penman, Netherl. J. Agric. Sci., Vol.5, pp.290-305, 1957

38）諸泉利嗣，小村拓也，三浦武志：Makkink式による可能蒸発量の推定精 度，水文・水資源学会誌，第 22 巻 6 号，pp.479-483， 2009

39) Saito T., Tanaka T., Tanabe H., Matsumoto Y., Morikawa Y.: Variations in transpiration rate and leaf cell turgor maintenance in saplings of deciduous broad-leaved tree species common in cool temperate forests in Japan, Tree Physiol., Vol.23, Issue 1, pp.59-66, 2003

40）国土交通省大臣官房技術調查課：国土交通省土木工事積算基準 平成17年 度版，p.891，建設物価調査会，2005.4

41) Jackson R.B., Canadell J., Ehleringer J.R., Mooney H.A., Sala O.E., Schulze E.D.: A global analysis of root distribution for terrestrial biomes, Oecologia, Volume 108, Issue 3, pp.389-411, 1996.11

42) Wilson K., Goldstein A., Falge E., Aubinet M., Baldocchi D. et al.: Energy balance closure at FLUXNET sites, Agric. For. Met., Vol.113, Issue 1-4, pp.223-243, 2002.12

43) Kume T., Tsuruta K., Komatsu H., Kumagai T., Higashi N., Shinohara Y., Otsuki K.: Effects of sample size on sap flux-based stand-scale transpiration estimates, Tree Physiol., Vol.30, Issue 1, pp.129-138, 2010

44) Santiago L.S., Mulkey S.S.: A test for gas exchange measurements on excised canopy branches of ten tropical tree species, Photosynthetica, Vol.41, No.3, pp.343-347, 2003.8

45）清野友規, 浅輪貴史, 梅干野昆, 清水克哉 : 重量計測に基づく単木蒸散量 の種間差の分析, 日本ヒートアイランド学会全国大会予稿集, pp.120-121, 2014.7

46) 浅輪貴史, 清野友規, 梅干野苌, 清水克哉 : 都市緑化を対象とした単木樹 の熱・水収支特性の計量化と数值モデル化その 10 樹種別の蒸散量の比 較分析とデータベース化, 日本建築学会大会学術講演梗概集, D-1, pp.873-874, 2014.9 


\title{
WEIGHING WHOLE TREE TRANSPIRATION RATE OF URBAN TREES AND ANALYSIS OF TREE'S MORPHO-PHYSIOLOGICAL EFFECTS
}

\author{
Tomoki KIYONO *, Takashi ASAWA **, Akira HOYANO *** \\ and Katsuya SHIMIZU**** \\ * Grad. Stud., Tokyo Institute of Technology, M. Eng. \\ * Assoc. Prof., Tokyo Institute of Technology, Dr. Eng. \\ *** Prof., The Open University of Japan, Dr. Eng. \\ **** TOYOTA Motor Corporation, Biotechnology \& Afforestation Business Div.
}

Transpiration effect is expected to mitigate urban thermal environment but efforts to predict urban trees' transpiration are complicated by our limited knowledge of how much and different whole tree's water use is. The difficulty in understanding urban trees' transpiration is mainly caused by the limitation of measurement method, so we newly developed hanging-type gravimeter method using container grown trees and beam-type load cells, which is convenient to weigh a number of samples in a short period.

The purpose of this study is to grasp the variation of whole tree transpiration rate of container-grown tree under isolated and irrigated condition which assuming urban environment and to analyze the relationship between trees' morpho-physiological characteristics and potential evaporation ratio. We weighed 11 popular urban tree species, Zelkova serrata, Quercus myrsinifolia, Styrax japonica, Cerasus x yedoensis, Ginkgo biloba, Quercus serrata, Cinnamomum camphora, Benthamidia japonica, Magnolia stellata, Quercus acutissima, Magnolia kobus at farm field, Aichi prefecture $\left(35^{\circ} 8^{\prime} \mathrm{N}, 137^{\circ} 6^{\prime} \mathrm{E}\right)$ in summer 2010, 2012 and 2013. Samples' soil volume were $0.5 \mathrm{~m}^{3}$, ranged $3 \sim 6.7 \mathrm{~m}$ in height, $1.5 \sim 9.2 \mathrm{~m}^{2}$ in crown projection area, deciduous/evergreen, and diffuse-porous/ring-porous/tracheid in xylem porosity.

We verified our new gravimeter accuracy using high time resolution recordings and autoregressive model and showed the mean value of relative error ( \pm 2 standard error) of all samples was $9.2 \%$ and the error of Quercus myrsinifolia in 2012, which use least water and have largest error, was $19.8 \%$ when wind velocity is under $2 \mathrm{~m} / \mathrm{s}$. We compared samples' transpiration rate of summer irrigation days and found (1)Daily water use of samples were $10 \sim 30 \mathrm{~kg}$, equivalent to $0.62 \pm 0.36$ times of water evaporation from the same size of crown projection area, (2)Maximum latent heat was $2.3 \mathrm{~kW} /$ tree of Zelkova serrata in 2010 and Quercus serrata, (3)Zelkova serrata and Quercus myrsinifolia changed transpiration capacity per unit leaf area threefold, appeared due to physiological change, (4)Ring-porous species tend to use much water ( $\mathrm{p}=0.045$ ), which suggest the significance of hydraulic capacity under volume-restricted soil condition. 